\title{
MID-CONTINENTAL JAEGERS: A MANITOBA PERSPECTIVE
}

\author{
PETER TAYLOR, P.O. Box 597, Pinawa, Manitoba. R0E 1L0
}

Jaegers and skuas are predatory birds, closely related to gulls. Whether they are seen on Arctic breeding grounds, on pelagic migration routes, or somewhere far inland, these birds create excitement among birders. They also have a reputation for turning up in unfamiliar or downright hostile surroundings. South Polar Skuas wander deep into Antarctica, even to the Pole itself. ${ }^{31}$ Even more remarkable, one was photographed at Lake Oahe, North Dakota, 13 July 1989. ${ }^{4}$ Long-tailed Jaegers have been seen on the Greenland icecap. ${ }^{72}$ Both Long-tailed and Pomarine Jaegers have been observed migrating over the Brooks Range of mountains in Alaska. ${ }^{12}$ Thus, mid-continental records are perhaps not surprising. All three jaeger species (Parasitic, Pomarine and Long-tailed) have occurred in most of the 50 states and every Canadian province (Long-tailed Jaeger is hypothetical in Prince Edward Island). ${ }^{17,32}$ This article reviews inland records of the three jaegers in Manitoba, in comparison with neighbouring regions.

A Note of Caution Adult jaegers in breeding plumage with their elongated central tail feathers are

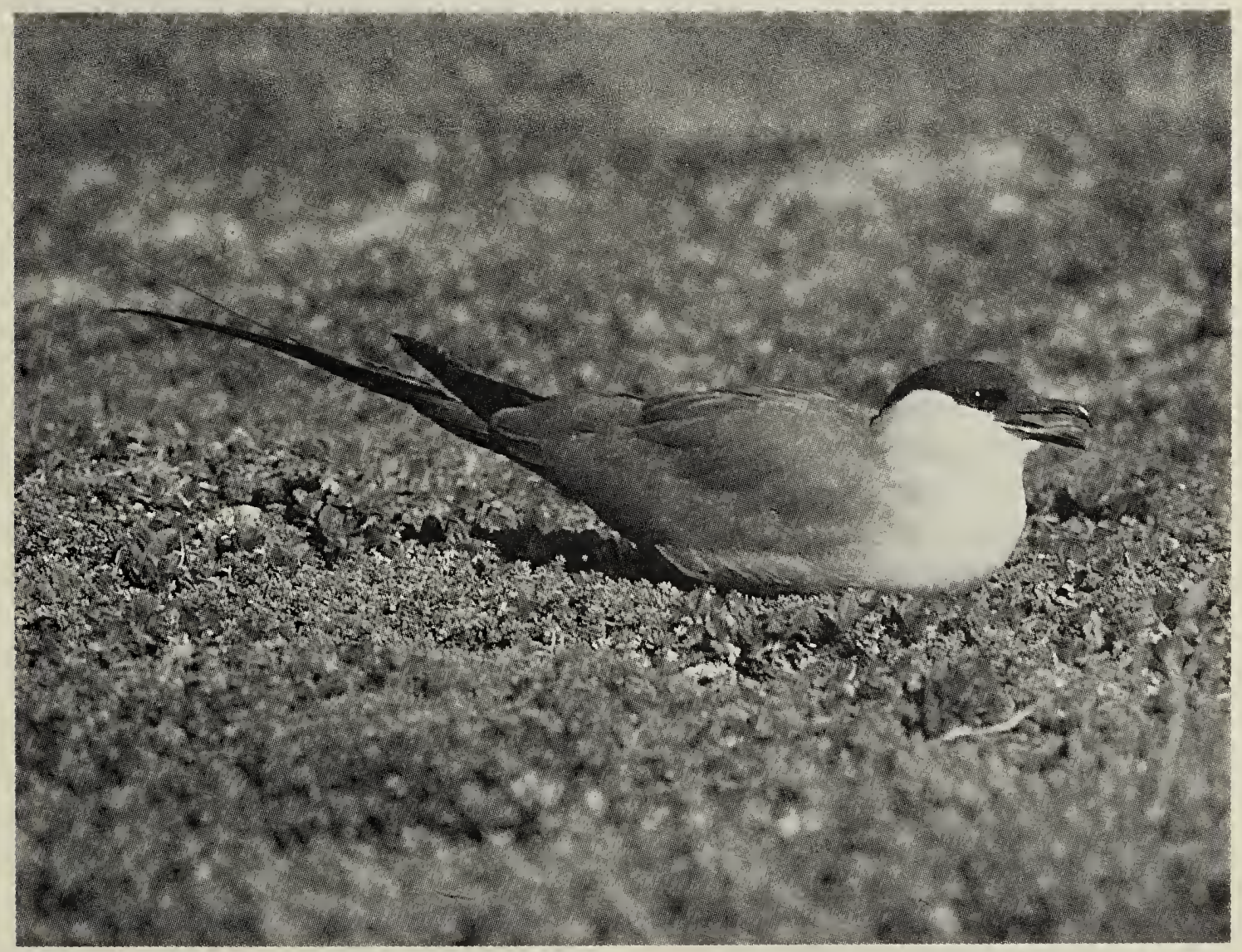




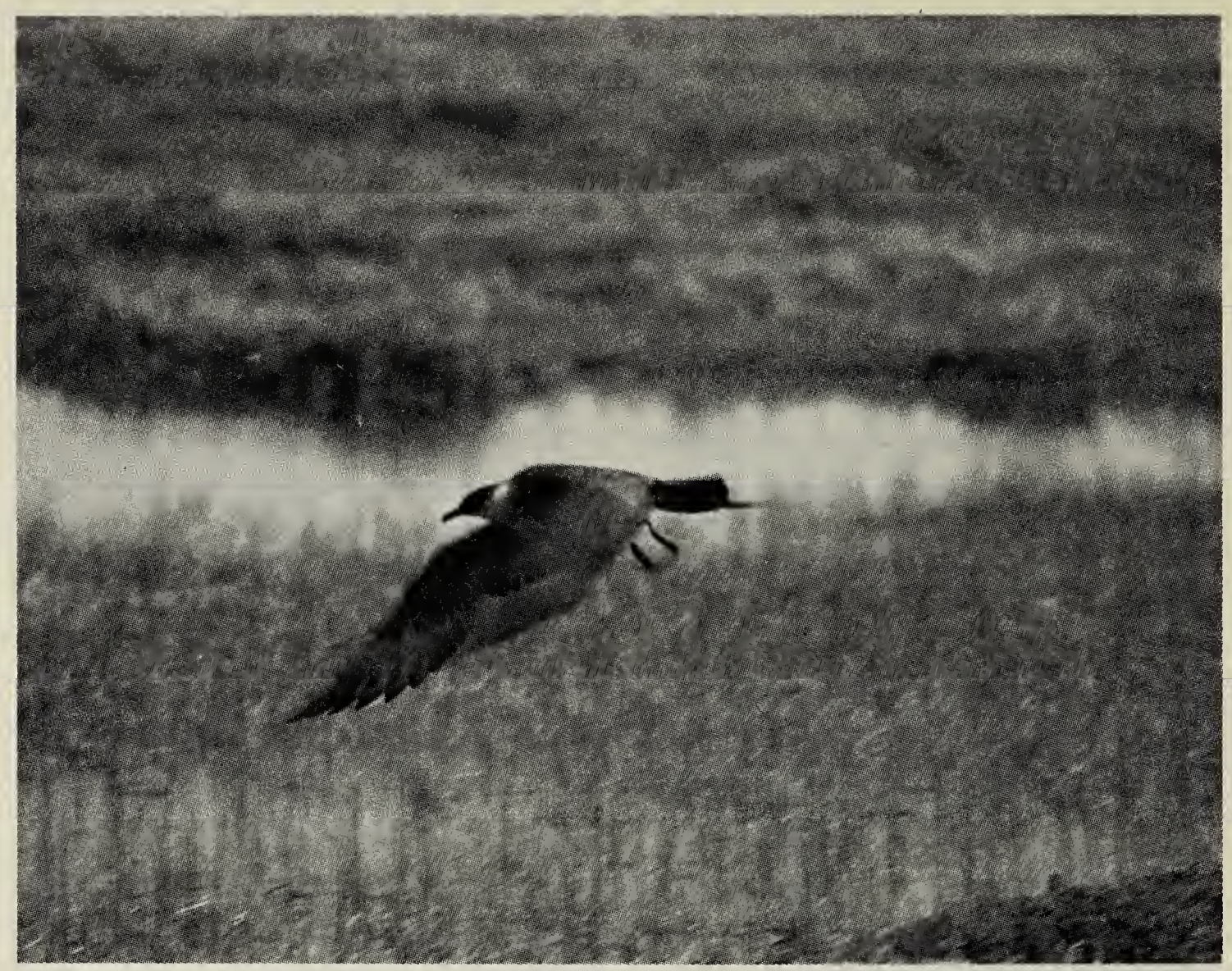

Parasitic Jaeger, Churchill, Manitoba, July 1982.

R.F. Koes

relatively easy to identify, but immature or transitional plumages present identification challenges, even in the hand. In an amusing (perhaps apocryphal) tale, a jaeger reportedly circled a boatload of birders three times, and was identified as a different species on each pass! ${ }^{8}$ Jaeger identification is often based on impressions of flight characteristics and proportions, which can vary with the bird's activity. A slowly cruising Parasitic Jaeger may seem bulky enough to be a Pomarine, then resemble a Long-tailed Jaeger when it slips into high gear after a passing tern. On the other hand, one might identify a poorly seen jaeger as Parasitic by default, when it is better left unnamed.

Analysis of Records Tables 1 and 2 summarize all records known to me of inland jaegers in Manitoba, including Long-tailed Jaeger records previously compiled by Crawshaw. ${ }^{11}$
In the following discussion, the status of the three species in Manitoba and neighbouring regions is compared. The review of neighbouring regions is admittedly not comprehensive.

Parasitic Jaeger This is the jaeger most frequently encountered in southern Manitoba, with 24 known records between 1918 and 1991 (Table 1A). The increase in frequency of sightings since 1970 (17 of the 24 records) presumably reflects increased observer effort and improved reporting. Similar increases have been noted for several other uncommon migrant water birds. ${ }^{74,75}$ Most records of Parasitic Jaegers involved single birds; three involved two individuals each, and as many as five may have been seen separately at St. Ambroise, 9 September 1989. Most records $(63 \%)$ were in September and October, and the remainder were 


\section{Table 1. ANNOTATED LIST OF JAEGER RECORDS IN MANITOBA}

\section{A. Parasitic Jaeger}

- 13 July 1918 , Pelican Island, n. LW. Light ad. found dead. ${ }^{58}$

- 25 Sept. 1929, Scanterbury (s.e. LW). Light ad. shot. ${ }^{10,44}$

- 14 June 1934, Pine Island, Lake St. Martin. Two birds. ${ }^{67}$

- 17 Oct. 1936, Husavick (s.w. LW). Dark imm. shot. ${ }^{46}$

- 20 Oct. 1940, Husavick (s.w. LW). Dark imm. found dead, MMMN \# 3.6-335. ${ }^{49}$

- 17 June 1961, Pinawa Channel (WR). One bird. ${ }^{53,54}$

- 1 Aug. 1966, Gimli (s.w. LW). Two light ad. ${ }^{69}$

- 9 June 1973, Whitewater Lake, RMNP. One bird. ${ }^{35}$

- 27 June 1973, Southern Indian Lake. Light ad. ${ }^{76}$

- 18 Sept. 1976, Oak Hammock Marsh. Dark bird. ${ }^{21}$

- 26-27 July 1978, St. Ambroise (s. LM). Light ad. photographed. ${ }^{34,65}$

- 30 Sept. 1979, St. Ambroise (s. LM). One: G. Holland, I. Ward.

- 6 Sept. 1980, Assiniboine Park, Winnipeg. One: G. Holland, R. Koes et al.

- Late June to about 10 July 1983, Clandeboye Beach (s. LM). One, unpublished photos: S. Haig.

- 13 Sept. 1986, Allegra. One light imm. flying s. over farmland: R. Knapton, R. Koes, P. Taylor (MORC). Cited as Winnipeg in American Birds.

- 18-19 Sept. 1987, Seven Sisters Falls (WR). One light imm.: R. Parsons, G. Grieef, P. Taylor (MORC).

- 11 Oct. 1987, Seven Sisters Falls (WR). One light imm.: P. Taylor (MORC).

- 15 Sept. 1988, nr. East Meadows Ranch (s.e. LM). One light, ad.?: R. Taylor.

- 26 Sept. 1988, Clandeboye Bay (s. LM). One light imm.: R. Parsons.

- 24 May 1989, Waskada/Deloraine. Two light ad. flying e., pursued $30 \mathrm{~km}$ by road: K. De Smet, M. Conrad.

- 9-17 Sept. 1989, St. Ambroise (s. LM). Five sightings in 4 hours on 9th: S. Holohan, J. Steeves. One light ad. on 11th (M. Siepman) and 17th (G. Grieef, R. Koes, R. Tkachuk).

- 13 Oct. 1991. St. Ambroise (s. LM). One bird: G. Holland, R. Koes.

- 19 Oct. 1991. Grand Beach (s.e. LW). One light bird: J. Weir.

- 20 Oct. 1991. Clandeboye Bay (s. LM) One dark bird. A Parsons, B Shettler.

\section{B. Long-tailed Jaeger}

\section{- Sept. 1896, LW. Dark imm. shot. ${ }^{66}$}

- 8 Oct. 1902, Clandeboye (s.w. LW). Imm. ${ }^{11,58}$

- 17 May 1903, Aweme. One shot. ${ }^{2,11,50}$

- 10 May 1940 , Pine Falls (WR). One bird. ${ }^{11,48}$

- 13-27 June 1969, nr. Thompson. Up to 29 birds. ${ }^{11,39}$

- 3 June 1973, between Roblin and Lake of the Prairies. One ad. flying n.e.: W. Neily (MBRC).

- 14 June 1982, Leaside Beach (w. LW). One light ad. caught; photos. ${ }^{11}$

- 14-18 June 1985, Seven Sisters Falls (WR). One light ad.: P. Taylor, P. Ingham et al. (MORC, MBRC).

- 4 June 1987, Dauphin Bay, Lake Winnipegosis. One light ad.: R. Knapton, unpublished report, Manitoba Wildlife Branch.

- 14 April 1989, Niverville. One light ad.: R. Dueck.

\section{Pomarine Jaeger}

- 19 Sept. 1932, Netley Marsh (s. LW). Imm. female found shot. ${ }^{45}$ MMMN \# 1.2-2066

- 30 Oct. 1975, Marshy Point (LM). Light ad. found dead. Emaciated (347 g). MMMN \# 1.2-3399.

Note: Observers' names are given only for unpublished records. A more detailed listing has been deposited with the Manitoba Ornithological Records Committee, and is also available from the author. This listing includes seven additional records of unidentified jaegers (see Table 2). ${ }^{11,47,55}$

Abbreviations: ad. $=$ adult, $\mathrm{imm} .=$ immature, $L M=$ Lake Manitoba, $L W=$ Lake Winnipeg, $M B=$ Manitoba, MBRC = Manitoba Bird Record Card at MMMN, MMMN = Manitoba Museum of Man and Nature (190 Rupert Ave., Winnipeg MB R3B 0N2), MORC = Manitoba Ornithological R'ecord Committee card at MMMN, RMNP = Riding Mountain National Park, WR = Winnipeg River. "Light" and "dark" refer to colour morphs ("phases"). Please send any information on missing specimens or additional records to the author. 
Table 2: SUMMARY OF MANITOBA JAEGER RECORDS BY MONTH, DATE AND LOCATION

\begin{tabular}{||l|c|c|c|c|}
\hline & Parasitic & Long-tailed & Pomarine & Unidentified $^{\star}$ \\
\hline April & 0 & 1 & 0 & 0 \\
\hline May & 1 & 2 & 0 & 2 \\
\hline June & 5 & 5 & 0 & 0 \\
\hline July & 2 & 0 & 0 & 0 \\
\hline August & 1 & 0 & 0 & 0 \\
\hline September & 9 & 1 & 1 & 0 \\
\hline October & 6 & 1 & 1 & 3 \\
\hline
\end{tabular}

\begin{tabular}{||c|c|c|c|c||}
\hline $1892-1911$ & 0 & 3 & 0 & 0 \\
\hline $1912-1931$ & 2 & 0 & 0 & 0 \\
\hline $1932-1951$ & 3 & 1 & 1 & 1 \\
\hline $1952-1971$ & 2 & 1 & 0 & 1 \\
\hline $1972-1991$ & 17 & 5 & 1 & 5 \\
\hline
\end{tabular}

\begin{tabular}{|l|l|l|l|l||}
\hline Lake Winnipeg & 6 & 3 & 1 & 2 \\
\hline Lake Manitoba & 8 & 0 & 1 & 2 \\
\hline Other lakes & 3 & 1 & 0 & 1 \\
\hline Winnipeg River & 3 & 2 & 0 & 0 \\
\hline Other rivers & 1 & 2 & 0 & 0 \\
\hline Elsewhere & 3 & 2 & 0 & 2 \\
\hline \multicolumn{5}{|l|}{} \\
\hline \multicolumn{7}{|l|}{ Totals } \\
\hline
\end{tabular}

scattered between May and August. Most sightings occurred at or near major lakes and rivers, especially Lakes Manitoba and Winnipeg. Noteworthy exceptions were birds apparently migrating overland near Deloraine in May 1989 and near Allegra in September 1986.

The Parasitic Jaeger is also the most frequent of the three species in Minnesota, where it is a rare but regular fall migrant on Lake Superior, most often seen in the Duluth area. $^{37,43}$ The Duluth records appear to represent the western limit of a migration route through the Great Lakes region. ${ }^{24,29,71}$ Other Minnesota records include one sighting (and an unidentified jaeger) on Lake of the Woods near the Manitoba border. $^{37,40,41}$ Duluth area records extend from early August to late
October, with a peak in early to midSeptember, resembling the southern Manitoban pattern (Table 2). In contrast, Janssen lists just five spring records in Minnesota. ${ }^{37}$ The Parasitic Jaeger is an accidental fall migrant in North Dakota, with about six records to 1990, and is unreported in South Dakota. $5,17,19,70$

Four Saskatchewan records of Parasitic Jaegers were reviewed by Bird. ${ }^{6}$ Fifteen fall reports in American Birds, 1976-1990, indicate a status similar to that in southern Manitoba, and there are also single observations in May, June and July. Farther west, there appears to be a sparse but regular movement of Parasitic Jaegers through Alberta, notably at Beaverhill Lake, and again with a peak in September. ${ }^{13,14,15,64}$ 
Long-tailed Jaeger This jaeger is the second most frequently reported inland in Manitoba (Table 1B). Only four of the ten records occurred prior to 1969. Except for the flock of up to 29 birds near Thompson in June 1969, all records involve lone birds. Half the records occurred in June, and only two in fall. Saskatchewan's first documented Long-tailed Jaeger occurred at Last Mountain Lake, 817 July $1982 .^{26,27}$ Previous sightings occurred in June, July (twice) and September. ${ }^{3,30,56,57,61}$ An exceptionally early report at Regina, 22 April 1989 , occurred just eight days after an equally surprising Manitoba sighting. ${ }^{28}$ One Minnesota record also occurred in April, one in July, and five in fall migration. ${ }^{37}$

Of 16 Alberta reports up to 1980 , only three were in June and the majority of recent sightings were in $\mathrm{Au}$ gust or early September. ${ }^{14,16,30,60,63,64}$ Excellent photographs document a September 1977 record at Beaverhill Lake. ${ }^{14}$ The Long-tailed Jaeger is a relatively recent addition to the state lists for both North and South Dakota. ${ }^{9,22,70}$ More southerly inland records in the U.S. have almost all been in the fall, but isolated June records extend south at least to Kansas. ${ }^{52}$

Pomarine Jaeger This is the rarest jaeger in southern Manitoba, with only two fall specimen records (Table 1C). By coincidence, the 1932 bird was found just three weeks before South Dakota's sole record; the species is unknown in North Dakota. ${ }^{7,19,70}$ In Minnesota, however, Pomarine Jaeger records outnumber those of Long-tailed Jaeger, as they do in Ontario, where "fall" records extend from late August to early January. ${ }^{36,37,71}$ Speirs cites only one spring record for Ontario, and Janssen only one for Minnesota. ${ }^{37,71}$
Saskatchewan's two Pomarine Jaeger specimens were obtained on 9 November 1922 and (amazingly) 30 December $1976 .{ }^{51,73}$ There are also about nine sight reports of Pomarine Jaegers in Saskatchewan (R. Kreba, pers. comm.), but published details are sparse. ${ }^{1,61}$ The Pomarine Jaeger is reported to leave the Arctic a few weeks later than the other two species, although this is not apparent in the Minnesota records. ${ }^{37,68}$ The Pomarine Jaeger was listed as hypothetical in Alberta by Salt and Salt. ${ }^{64}$ The most fully described of four sight records was at Lake Athabasca, 6 June 1969. ${ }^{15,33,60,63}$

Discussion The three jaegers show three different patterns of rare occurrence in southern Manitoba, as outlined above. Do these records represent random wanderings inland, or are they evidence of "shortcut" migration routes between the Arctic and warm oceans? Such routes have been postulated for Arctic Tern and Sabine's Gull, as well as jaegers. ${ }^{23,38,62}$ Overland migration of Parasitic Jaegers in Africa and the former Soviet Union appears to be well documented. ${ }^{20}$

The relative frequency of occurrence of the three jaeger species in southern Manitoba parallels the southward extent of their breeding ranges. The Parasitic Jaeger nests as far south as coastal Manitoba and Ontario. ${ }^{24,38,59}$ The southern limit of the Long-tailed Jaeger's breeding range is near the Manitoba-Keewatin border, and this species is a regular migrant at Churchill (arriving overland?). ${ }^{24,38}$

The Pomarine Jaeger nests mainly north of the Arctic Circle, and is a rarity even at Churchill. ${ }^{24,38}$ Note, however, that the frequency of occurrence of vagrants or rare 
migrants is a function of total population and other factors as well as geographic proximity.

Parasitic Jaegers nesting around southern Hudson Bay could benefit from a migration route to the Atlantic via the Great Lakes, if the risks of overland migration are not too great. Migrant seabirds in southern Manitoba, however, do not necessarily originate in or near northern Manitoba. Extremely rare visits to southern Manitoba by Common Eiders, for example, originate from Alaska or the Beaufort Sea, not Hudson Bay. ${ }^{42}$ The similar frequencies of Parasitic Jaeger records in Saskatchewan and southern Manitoba point to a sparse, broad-front movement from the Arctic, rather than the fringe of a migration from Hudson Bay.

This suggested movement of jaegers could lead southeastward to the Great Lakes and the Atlantic, southward to the Gulf of Mexico, or southwestward to the Pacific. The similar timing of Parasitic Jaeger records in southern Manitoba and Minnesota, and the absence of South Dakota records, tend to support the first of these three routes. Jaeger records in the Gulf of Mexico between November and April, however, indicate that some birds complete an overland migration, possibly following the Mississippi River. ${ }^{18,77}$ Jaegers seen in Alberta in fall are likely Pacific-bound. The concentration of southern Manitoban Longtailed Jaeger records in June coincides with migration at Churchill, but not with broader patterns in neighbouring regions, where fall records predominate.

The scarcity of Pomarine Jaeger records in southern Manitoba is consistent with this species' general scarcity in mid-continent, although a few overwinter in the Gulf of Mexico. ${ }^{18,77}$ Details of inland movements of all the jaegers are likely to remain a mystery, however, unless sophisticated tracking methods such as satellite telemetry can be applied to the problem.

Acknowledgements I thank Herb Copland, Ross Dickson, Richard Knapton, Rudolf Koes, Martin McNicholl, Henri Ouellet, Spencer Sealy, John Steeves and Reto Zach for information and helpful comments on various draft manuscripts.

1. ANONYMOUS. 1944. Bird notes. Blue Jay 2:31.

2. ATKINSON, G.E. 1904. Rare bird records of Manitoba. Historical and Scientific Society of Manitoba Transactions 65:1-12.

3. BELCHER, M. 1980. Birds of Regina, revised edition. Special Publ. No. 12. Sask. Nat. Hist. Soc., Regina. 152 pp.

4. BERKEY, G. 1989. The nesting season. June 1 - July 31, 1989. Northern Great Plains Region. Am. Birds 43:1332-1334; also pp. 1279 and 1282.

5. - 1991. The autumn migration. August 1 - November 30, 1990. Northern Great Plains Region. Am. Birds 45:120-122.

6. BIRD, C.D. 1957. The Parasitic Jaeger in Saskatchewan. Can. FieldNat. $71: 37$.

7. BRECKENRIDGE, W.J. 1933. The Pomarine Jaeger in South Dakota. Wils. Bull. 45:79.

8. BROCK, K.J. 1991. The role of probability in bird identification: is bird identification a crapshoot, or are birders just dicey? Birding 23:292294.

9. BURGESS, H. 1975. Long-tailed Jaeger: new record for South Dakota. South Dak. Bird Notes 27:69.

10. CARTWRIGHT, B.W. 1931. Notes and observations on some Manitoban Birds. Can. Field-Nat. 45:181-187.

11. CRAWSHAW, G.J. 1984. Long-tailed Jaeger in southern Manitoba. Blue Jay 42:221-223.

12. DEAN, F.C., P. VALKENBURG and A.J. MACOUN. 1976. Inland migration of Jaegers in northeastern Alaska. Condor 78:271-273. 
13. DEKKER, D. 1968. Autumn records of Parasitic Jaegers in central Alberta. Blue Jay 26:16-17.

14. _ 1979. Long-tailed Jaeger preys on Lesser Yellowlegs. Blue Jay $37: 221-222$.

15. - 1985. Jaegers at Beaverhill Lake, Alberta. Alberta Naturalist 15:14.

16. 1985. Wild hunters. Canadian Wolf Defenders, Edmonton. Chapter 21.

17. DESANTE, D. and P. PYLE. 1986. Distributional checklist of North American birds. Vol. 1. United States and Canada. Artemisia Press, Lee Vining, California. $442 \mathrm{pp}$.

18. DUNCAN, C.D. and R.W. HAVARD. 1980. Pelagic birds of the northern Gulf of Mexico. Am. Birds 34:122132.

19. FAANES, C.A. and R.E. STEWART. 1982. Revised checklist of North Dakota Birds. Prairie Nat. 14:81-92.

20. FURNESS, R.W. 1987. The Skuas. T. \& A.D. Poyser, London, U.K. 363 pp.

21. GARDNER, K.A. 1981. Birds of Oak Hammock Marsh Wildlife Management Area. 172 pp. Available from Manitoba Museum of Man and Nature, Winnipeg.

22. GATZ, T. and D. TREASURE. 1979. First record of Long-tailed Jaeger for North Dakota. Prairie Nat. 11:5-6.

23. GODFREY, W.E. 1973. A possible shortcut spring migration route of the Arctic Tern to James Bay, Canada. Can. Field-Nat. 87:51-52.

24. _ 1986. The birds of Canada, revised edition. Natl. Mus. Can., Ottawa. 595 pp.

25. GOLLOP, J.B. 1965. Some 1964 bird records for the Saskatoon district. Blue Jay 23:13-14.

26. _ 1982. Some June-July bird records for the Prairie Provinces. Blue Jay 40:193-196.

27. 1982. The nesting season. June 1 - July 31, 1982. Prairie Provinces region. Am. Birds 36:989.

28. — 1989. The spring season. March 1 - May 31, 1989. Prairie Provinces region. Am. Birds 43:495-497.

29. GOODWIN, C.E. 1977. The fall migration. August 1 - November 30, 1976. Ontario region. Am. Birds 31:171.

30. HALLADAY, I.R. 1966. Long-tailed Jaeger in Alberta. Blue Jay 24:141 (1966).

31. HALLE, L.J. 1973. The sea and the ice: a naturalist in Antarctica. Chapter
11. The skua. Houghton Mifflin, Boston. 280 pp.

32. HOGAN, G. 1991. Familiar birds of Prince Edward Island. Ragweed, Charlottetown. 152 pp.

33. HOHN, E.O. 1970. Pomarine and Parasitic Jaegers and Sabine's Gull in Alberta. Can. Field-Nat. 84:402.

34. HORCH, P. 1978. Bird news. Man. Nat. Soc. Bull. 1:6.

35. HOUSTON, C.S. 1973. The nesting season. June 1 - July 31, 1973. Northern Great Plains. Am. Birds 27:884.

36. JAMES, R.D. 1991. Annotated checklist of the birds of Ontario. Second edition. Royal Ontario Museum, Toronto. $128 \mathrm{pp}$.

37. JANSSEN, R.B. 1987. Birds in Minnesota. University of Minnesota Press, Minneapolis. $352 \mathrm{pp}$.

38. JEHL, J.R., Jr. and B.A. SMITH. 1970. Birds of the Churchill region, Manitoba. Special Publ. No. 1, Manitoba Mus. Man and Nat., Winnipeg. $87 \mathrm{pp}$.

39. JOHNSON, J.W. 1970. A bird list for Thompson, Manitoba. Blue Jay 28:14-19.

40. JOHNSTON, A. 1984. Sabine's Gull and Jaeger on Lake of the Woods. Loon 56:266-267.

41. 1985. Parasitic Jaegers on Lake of the Woods. Loon 57:179.

42. KOES, R.F. 1987. Common Eider, Somateria mollissima $v$-nigra, in southern Manitoba. Can. Field-Nat. 101:110-111.

43. LAMEY, T. 1982. Record number of Jaeger sightings. Loon 54:46-48.

44. LAWRENCE, A.G. 1929. Parasitic Jaeger shot. Chickadee Notes No. 447. Winnipeg Free Press, 11 November 1929.

45. _ 1932. Pomarine Jaeger visits southern Manitoba. Chickadee Notes No. 607. Winnipeg Free Press, 11 November 1932.

46. 1936. Robber gull at Husavick. Chickadee Notes No. 818. Winnipeg Free Press, 27 November 1936.

47. 1938. Review by Kjarna S.D. [School Division] Bird Club. Chicka- 
dee Notes No. 913. Winnipeg Free Press, 23 September 1938.

48. - 1940. Chickadee Notes No. 999. Winnipeg Free Press, 17 May 1940.

49. - 1940. Chickadee Notes No. 1025. Winnipeg Free Press, 15 November 1940.

50. MACOUN, J. and J.M. MACOUN. 1909. Catalogue of Canadian birds. Geological Survey Branch, Canada Dept. of Mines, Ottawa. 761 pp.

51. MITCHELL, H.H. 1924. Birds of Saskatchewan. Can. Field-Nat. 38:101118.

52. MOSBY, L.D. and LYNN, W.M. 1956. Long-tailed Jaeger in Kansas. Wils. Bull. 68:245.

53. MOSSOP, H. 1961. The wanderer from the north. Chickadee Notes No. 337. Winnipeg Free Press, 1 July 1961.

54. 1961. The Parasitic Jaeger. Chickadee Notes No. 338. Winnipeg Free Press, 8 July 1961.

55. 1962. Chickadee Notes No. 384. Winnipeg Free Press, 26 May 1962.

56. NERO, R.W. 1963. Birds of the Lake Athabasca region, Saskatchewan. Special Publ. No. 5, Sask. Nat. Hist. Soc., Regina. 143 pp.

57. NERO, R.W. and C.S. HOUSTON. 1963. Additions to the check-list of Saskatchewan birds. Blue Jay 21:132-133.

58. O'DONOGHUE, C.H. and J.N. GOWANLOCK. 1919. Notes on the Caspian Tern (Sterna caspia) and the Parasitic Jaeger (Stercorarius parasiticus) in Manitoba. Can. Field-Nat. 33:1-6.

59. PECK, G.J. 1987. Parasitic Jaeger. P. 537 in Atlas of the breeding birds of Ontario, compiled by M.D. Cadman, P.F.J. Eagles and F.M. Helleiner. University of Waterloo Press.

60. PINEL, H.W., W.W. SMITH and C.R. WERSHLER. 1991. Alberta birds, 1971-1980. Volume 1. Non-passerines. Nat. Hist. Occas. Paper 13, Prov. Mus. of Alberta, Edmonton. 243 pp.

61. RANDALL, T.E. 1962. Birds of the Kazan Lake region, Saskatchewan.
Blue Jay 20:60-72.

62. RYFF, A.J. 1986. The spring mystery of Sabine's Gull. Birding 18:83-90.

63. SADLER, T.S. and M.T. MYRES. 1976. Alberta Birds 1961-1970. Occas. Paper No. 1, Prov. Mus. of Alberta, Edmonton.

64. SALT, W.R. and J.R. SALT. 1976. The Birds of Alberta, with their ranges in Saskatchewan and Manitoba. Hurtig, Edmonton. 498 pp.

65. SERR, E.M. 1978. The nesting season. June 1 - July 31,1978 . Northern Great Plains region. Am. Birds 32:1177.

66. SETON, E.T. 1908. Recent bird records for Manitoba. Auk 25:450-454.

67. SHORTT, T.M. and S. WALLER. 1937. The birds of the Lake St. Martin region, Manitoba. Contrib. Royal Ont. Mus. Zool. No. 10.

68. SMALL, A. 1974. The birds of California. Macmillan, New York. 310 pp.

69. SMITH, G., H. COPLAND, M. MCNICHOLL and V. SCOTT. 1966. Breeding bird season 1966. Nat. Hist. Soc. Man. Newsletter 14:12-16.

70.SOUTH DAKOTA ORNITHOLO GISTS UNION. 1991. The Birds of South Dakota. Revised edition. Aberdeen, SD. 411 pp.

71. SPEIRS, J.M. 1985. Birds of Ontario, vol. 2. Natural Heritage, Toronto.

72. SUTTON, G.M. 1951. Review of "The Birds of Greenland" by F. Salomonsen. Wils. Bull. 63:350-352.

73. SYROTEUK, M. 1977. Second Saskatchewan specimen of Pomarine Jaeger. Blue Jay 35:165-166.

74. TAYLOR, P. and R.F. KOES. 1987. Scoter migration in southeastern Manitoba, 1975-1986. Blue Jay 45:166-171.

75. TAYLOR, P. and J.E. THOMPSON 1990. Harlequin Duck in Manitoba: an update. Blue Jay 48:98-103.

76. WEBER, W.C. 1976. Birds of Northcentral Manitoba, 1973. Blue Jay 34:84-94.

77. WILLIAMS, L.E., Jr. 1965. Jaegers in the Gulf of Mexico. Auk 82:19-25. 